\title{
ВОСПРОИЗВЕДЕНИЕ ИСТОРИЧЕСКОГО ОПЫТА САМООРГАНИЗАЦИИ В ИНОКУЛЬТУРНОЙ СРЕДЕ НА ПРИМЕРЕ ДЕЯТЕЛЬНОСТИ ХАЗАРЕЙСКОЙ СТУДЕНЧЕСКОЙ АССОЦИАЦИИ «КАТИБ» В МОСКВЕ
}

Статья посвящена мигрантам из Исламской республики Афганистан - хазарейцам, проживающим в Москве. На примере «Студенческой научно-культурной ассоциации “Катиб” в РФ» рассматриваются вопросы внутренней самоорганизации и сочиализации хазарейцев в инокультурном обществе. Показанные механизмы адаптации выработаны на основе исторического опьтта и часто отсылают к региону исхода. Взаимоотношения хазарейщев с представителями других «афганских» этнических групп в Москве во многом повторяют ситуачию в самом Афганистане.

Ключевые слова: Москва, хазара, миграция, Афганистан, национальные организащии

Для цитирования: Сеитов Э.М. Воспроизведение исторического опыта самоорганизации в инокультурной среде на примере деятельности хазарейской студенческой ассоциации «Катиб» в Москве // Вестник антропологии, 2021. № 4. С. 230-250.

В изучении миграций важно анализировать не только их причины, но и процессы внутренней самоорганизации и взаимопомощи мигрантов. В статье на примере хазарейской «Студенческой научно-культурной ассоциации “Катиб” в РФ», созданной студентами и поддерживаемой предпринимателями, будут рассмотрены механизмы адаптации хазарейцев в инокультурной среде. Автор придерживается следующей позиции: чтобы исследование сообществ мигрантов было полноценным и качественным, нужно уделять внимание политическим, культурным и социальным реалиям региона/страны исхода.

Настоящая статья - часть актуального исследовательского проекта автора «Шиизм в Московском регионе», целью которого является изучение различных сторон жизни шиитских (имамитских) общин, представленных выходцами из Закавказья (азербайджанцами, талышами) и Южной Азии («пакистанцами» и «афганцами»: хазарейцами, гератцами, кызылбашами). Специальных исследований шиитских общин в Москве не проводилось, данная публикация, по сути, открывает тему.

Сеитов Эрик Мусаевич - аспирант, стажер-исследователь, Институт этнологии и антропологии РАН (Ленинский пр. 32а, Москва, 119991, Россия). Эл. почта: telcorp@list.ru

* Материал публикуется в соответствии с планом НИР ИАЭ РАН 


\section{История и этносоциальное положение хазарейцев в Афганистане}

Хазарейц̧ь или хазара (хезаре) - одна из этнических групп, населяющих современный Афганистан. По приблизительным данным, общая численность хазарейцев составляет от 5 до 8 млн человек, из них более 4 млн проживают на территории Афганистана (Minahan 2014: 99). Согласно Конституции Афганистана 2004 г., за хазарейцами признается статус одной из 14 этнических групп, входящих в состав «афганской нации». Исторически местом расселения хазарейцев является область Хазараджат (Хезареджат), иногда в прошлом именовавшаяся Сададжат (Туркман 1916: 707), - это центральная часть современного Афганистана, расположенная севернее Кабула. Относительно большие группы хазарейцев проживают в различных городах страны - Мазари-Шарифе, Герате, Газни, Кабуле (в пригороде Дашт-е-Барчи), а также в провинциях Газни, Чор, Урузган, Вардок. Общины хазарейцев есть в Квете (Исламская Республика Пакистан) и Мешхеде (Исламская Республика Иран), в последние 40 лет они появились в странах Европы, Северной Америки и в Австралии.

Большинство хазарейцев - мусульмане шииты, есть среди них небольшое число исмаилитов и суннитов. Конституция Афганистана 2004 г. признает шиитский толк ислама, его правовые и юридические аспекты. Языком хазарейцев является дари (фарси-кабули) - один из двух (второй - пушту) государственных языков Афганистана, распространенный на севере и в центральной части страны, за языками некоторых других этнических групп закреплен статус локальных (Ibrahimi 2017: 3).

Существуют различные версии происхождения хазарейского этноса, связанные с их антропологическим обликом, в котором присутствует некоторая монголоидность, выраженная в разной степени у разных групп (Ferdinand 1959: 18-50; Schurmann 1962: $112-115,119,156)$. Одна из популярных версий этногенеза - происхождение хазарейцев от солдат Чингизхана (Bellew 1879: 204, 225-226; 1880: 114). В.В. Бартольд также склонялся к такому объяснению: он писал о монголах, переселившихся в центральные части Афганистана во времена Никудерийской орды в XIII в., от которых, по всей вероятности, и берут свое начало хазарейцы (Бартольд 1903: 55; Петрушевский 1960: 41-42). Существовала и другая версия, распространенная среди советских ученых: этнос появился в результате слияния пришлых тюрко-монгольских племен с местным иранским элементом (Темирханов 1972: 20-24; Кисляков 1973: 130-139).

Для подтверждения своего автохтонного происхождения хазарейцами активно используется буддийское прошлое региона: в числе своих предков хазарейцы признают население в прошлом локального центра буддизма провинции Бамиан в пределах Хазараджата (Verardi 2012). Доказательством тому служат две статуи Будды VI в. н.э., уничтоженные движением Талибан ${ }^{1}$ в 2001 г. Уничтожение талибами этих статуй в Бамиане, по мнению многих хазарейцев, - акт уничтожения их исторической памяти (Husseini 2012).

С.А. Мусави в своей монографии 1997 г. выдвинул оригинальную версию, предполагающую существование древней цивилизации Бамиана, которая и стала отправной точкой в этногенезе хазарейцев. С.А. Мусави отметил, что этот регион, имевший важное стратегическое значение, часто упоминается в различных письменных источниках. Существенное влияние на демографические процессы, согласно автору, сыграло переселение в Хазараджат буддийских монахов из Тибета, которые распро-

\footnotetext{
${ }^{1}$ Талибан (талибы) - террористическая организация, запрещенная на территории России.
} 
странили свою религию среди местного населения. В X-XV вв. на хазарейцев оказали культурное влияние пришлые тюрко-монгольские племена (Mousavi 1997: 37-43).

Этногенез и историческая память рассматриваются в качестве важного политического фактора всеми народами современного Афганистана. Так, пуштуны (вернее, пуштунские племена и кланы), доминирующие в политической системе Исламской республики, склоняются к пуштуно-центричному трактованию истории страны, которое зачастую не оставляет места другим этническим общностям. Пуштунский национализм зародился в 30-е годы XX в., когда появилась идея об «арийском» прошлом этого народа, связанная с одним из потерянных «колен израелевых». Конструирование истории было попыткой обосновать доминирующее положение пуштунской элиты на политической арене Афганистана (Schetter 2005: 8). Наделяя пуштунские племена и таджикское население страны статусом «коренных» народов, пуштунский этнонационализм «выводил» из числа «автохтонных» другие крупные общности: узбеков, туркмен, белуджей и др. Хазарейцев стали считать потомками пришлых «монголов» и на этом основании перестали относить их к «истинным» жителям Афганистана (Wafayezada 2013: 98-99). Отголоски пуштунского национализма проявляются и сегодня: его установки, наряду с исламским компонентом, присутствуют в идеологии движения «Талибан», костяк которого составили пуштунские племена и кланы (Zulfacar 2006: 42-49).

\section{Опыт взаимодействия хазарейцев с государственными режимами}

Правители Дурранийской империи (1747-1823) ${ }^{1}$, опиравшиеся на различные пуштунские племена, заложили фундамент для дальнейшего доминирования пуштунов в политической, культурной и социальной сфере (Ibrahimi 2017: 27). Во второй половине XVII - начале XVIII в. власти не только вводили повышенные налоги и денежные поборы для непуштунского населения, но и переселяли отдельные пуштунские племена в ареал проживания хазарейцев. С распадом Дурранийской империи и образованием Афганского эмирата, а особенно во времена правления «железного эмира» Абдур Рахман Хана (1880-1901), ситуация ухудшилась. Правление Абдур Рахман Хана отмечено высоким уровнем насилия, многочисленными восстаниями (около 40), из которых четыре описывались самим эмиром как «гражданские войны» (Khan 1900: 249). В 1880-1881 гг. войска Абдур Рахман Хана покорили независимые районы Хазараджата, а в 1892-1893 гг. жестоко подавили восстание хазарейцев. В исторической памяти народа эти события сохранились как «государственный геноцид» (Темирханов 1978: 12-26).

Последствием завоевания Хазараджата «железным эмиром» стали упадок и деградация сельскохозяйственных угодий, занятых пуштунскими кочевниками и превращенных в пастбища (Ferdinand 1962). По различным оценкам, около половины населения Хазараджата было истреблено, часть вынуждена была бежать в Британскую Индию, Персию, Российский Туркестан и Бухарский эмират (Mousavi 1997: 139-154). В результате завоевания Хазараджата изменилась традиционная родо-

\footnotetext{
${ }^{1}$ Дурранийская империя - историческое пуштунское государство, включавшее в себя территорию современных Афганистана, Пакистана, северо-восточную часть Ирана и западную часть Индии. Была основана в Кандагаре в 1747 г. полководцем Ахмад-шахом Дуррани. Дурранийская империя часто рассматривается как предтеча современного афганского государства.
} 
племенная структура хазарейского общества: после физического уничтожения части племен на смену родоплеменным образованиям - каумам ${ }^{1}$ во главе с мирами и бузургами пришли группы, создававшиеся по территориальному принципу. Эти группы, включавшие и остатки прежних племен, могли называться так же, как каумы, на территории которых новые образования расселялись. После насильственного присоединения Хазараджата и разрушения традиционного экономического уклада региона, хазарейцы оказались в положении маргинализированного меньшинства в «афганском государстве». Это положение подкреплялось с помощью религиозных инструментов: фетвы некоторых афганских богословов выводили шиизм и его последователей из «разряда» правоверных мусульман (Mousavi 1997: 114).

После смерти эмира Абдур Рахман Хана в 1901 г. В отношении хазарейцев наметилась некоторая «оттепель». Но до 1978 г. В «централизованном» Афганистане этот народ находился в экономической кабале (обложенный высокими налогами и денежными поборами). Хазарейцы были исключены из политической и социально-экономической жизни афганского государства (Mousavi 1997: 155-171; Emadi 1997). Правительство жестко контролировало их жизнь через сеть шпионов и доносчиков, а также посредством экономического давления на «традиционную элиту» - независимых землевладельцев (миры и беги), видя в них «элемент самоуправления» (Canfield 1972: 5). В то же время власти поощряли лояльных им миров и малеков, выделяя им денежные средства и ставя в прямую зависимость от режима (Mousavi 1997: 132).

В XX в. хазарейцы были практически полностью исключены из системы государственного образования. Первая школа в Хазараджате (в округе Рагул, Бесуди) открылась только в 1938 г. По официальным данным, во всем Афганистане к 1961 г. насчитывалось 1436 школ, в то время как в регионах, населенных хазарейцами, было всего 20 начальных сельских школ (Laali 1993: 356).

С начала XX в. вплоть до 1978 г. В хазарейском обществе постепенно усиливается роль сейидов - религиозных авторитетов, принявших на себя и социальные функции, связанные с внутренней жизнью общин. Социальный статус сейидов базировался на их признанном родстве с Пророком Мухаммедом. Упрочению положения сейидов в хазарейском обществе немало способствовало их устойчивое финансовое положение, поскольку все они получали хумс - денежные средства, которые обычно верующие шииты собирают в пользу потомков Пророка. В ситуации исключения хазарейцев из системы государственного образования функции начального обучения взяли на себя мечети и медресе во главе с сейидами. Уже в 60-е годы ХХ в. наметилась тенденция к получению частью юношей хазарейцев высшего религиозного образования за пределами Афганистана, в хауза $a^{2}$ Ирака и Ирана. Медленно формировавшаяся хазарейская интеллигенция представляла собой небольшую прослойку «элиты» выходцев из числа состоятельных землевладельцев и клерикальных кругов.

Ситуация в Хазараджате начала кардинально меняться после Саурской революции 27 апреля 1978 г., когда власть в Кабуле взяла Народно-демократическая партия Афганистана (НДПА). Революционное правительство декларировало следующие задачи: борьбу с неграмотностью, равноправное положение женщины в обществе, широкое присутствие государства в экономике, устранение феодализма и его пе-

\footnotetext{
${ }^{1}$ Каум в Афганистане довольно широкое понятие, к примеру, так могут именоваться жители одной деревни, работники артелей, многочисленные близкие родственники.

${ }^{2}$ Шиитские учебные заведения.
} 
режитков и ликвидацию дискриминации по этническому признаку (Ibrahimi 2017: 118). Последние два положения затрагивали напрямую хазарейское общество, угнетаемое и афганским государством, и местными феодалами.

В 1979 г. хазарейцы подняли восстание в Хазараджате, самым главным его результатом стало обретение областью впервые за 100 лет политической независимости от Кабула (Ibrahimi 2017: 144-175). В образовавшемся вакууме власти усилились позиции организации «Шура», объединившей представителей духовенства (улемов, сейидов) и традиционной элиты (миров, ханов, малеков). Влияние «Шуры» в Хазараджате существенно ослабло к середине 1980-х годов, когда на смену ей пришли «партии» (военные группировки), боровшиеся уже между собой за сферы влияния в регионе. В этот период в обществе возросла роль «военных лидеров»- выходцев из простого народа, которые потеснили традиционную элиту.

После победы Иранской революции 1979 г. Иран стал активно распространять свое военное и идеологическое влияние на соседние страны, в том числе на Афганистан, где он поддерживал некоторые шиитские военизированные группировки Хазараджата. Следствием этой поддержки стало выдвижение в качестве «новых лидеров» хазарейцев шиитских моджахедов ${ }^{1}$, социальный капитал которых определялся не только их личными качествами, но и военной помощью соседнего государства. Вооружившись экспортированной из Ирана идеологией, «новые лидеры» выступили с радикальными предложениями по переустройству традиционного общества Хазараджата. Они видели изъяны хазарейского общества в «феодальных пережитках», поддерживаемых «традиционной элитой», а также в клановом и племенном делении (см. более подробно: Harpviken 1995).

В конце 1980-х годов в регионе появилась партия «Хезб-э Вахдат» («Партия Единства»), программа которой предусматривала объединение политических и военных группировок Хазараджата. Несмотря на исламский идеологический уклон, партия была открыта для хазарейцев любой политической ориентации. Не остался без внимания и женский вопрос: в Центральный совет «Хэзб-э Вахдат» вошли десять женщин, получивших светское университетское образование (Ibrahimi 2017: 182). Умело совмещая исламскую и национальную риторики, «Хезб-э Вахдат» добилась того, что общество воспринимает ее как силу, представляющую хазарейцев на политической арене страны. Харизматичный Генеральный секретарь партии Абдул Али Мазари, или «Баба Мазари» (1946-1995), стал и этническим лидером, а после своей смерти от рук талибов получил ореол мученика. Обретение хазарейцами своего национального лидера имело особую значимость, так как после низложения прокоммунистического режима в Афганистане политические партии и региональные группировки стали консолидироваться во многом по этническому и региональному признакам.

\footnotetext{
${ }^{1}$ Дословно «упорный, усердный»; термин многозначный, в данном случае «моджахед» - участник военного сопротивления режиму НДПА в ДРА. Помимо суннитских моджахедов в период 1979-1989 гг. В регионах Афганистана, населенных шиитами, действовали и шиитские моджахеды из военно-политического союза «Коалиционный совет исламской революции Афганистана» («Шиитская восьмерка»), куда входили различные военные/политические группировки. Шиитские моджахеды активно поддерживались Ираном. Основной задачей «Шиитской восьмерки» была вооруженная борьба против ограниченного контингента советских войск в Афганистане и правительственных сил ДРА, а также противодействие усилению суннитских моджахедов, поддерживаемых ЦРУ в рамках «операции Циклон».
} 
После падения Демократической Республики Афганистан (ДРА) в апреле 1992 г. многие бывшие члены госаппарата, партийные деятели, высокопоставленные военные и сотрудники спецслужб пополнили ряды группировок, возглавляемых полевыми командирами моджахедами. К примеру, большинство бывших пуштунских «коммунистов» из НДПА влились в отряды «Хэзб-э Ислами» во главе с пуштуном Гульбеддином Хекматияром, таджикские функционеры НДПА пополнили отряды Ахмад Шаха Масуда, таджика по национальности. Для узбеков и туркмен Афганистана центром притяжения стали отряды Абдул Рашида Дустума, бывшего командующего 53 дивизией правительственных войск ДРА (HRW 2005: 17). Появились и региональные лидеры, такие как Туран Исмаил в провинции Герат. Группировки моджахедов поделили сферы влияния с учетом границ расселения этнических и региональных групп. Все это привело к децентрализации Афганистана и ослаблению государственных институтов (Коргун 2005: 52-60).

Движение «Талибан», появившееся в 1994 г. В провинции Кандагар, населенной в основном пуштунами, заявило одной из своих целей прекращение гражданской войны и формирование центрального правительства. Если большинство жителей Афганистана воспринимало талибов как военно-политическую силу с исламистским уклоном, то для хазарейцев они стали воплощением пуштунского доминирования и угрозой независимости Хазараджата, следствием чего станет очередное подчинение Кабулу.

Одним из значимых событий гражданской войны стало нанесение отрядами хазарейцев в 1997 г. первого военного поражения до этого считавшимся непобедимыми талибам, штурмовавшим г. Мазари-Шариф. Эта победа повысила статус хазарейцев в афганском обществе и стала важным компонентом их коллективной памяти. Однако победа была недолгой, уже в 1998 г. талибы овладели северными провинциями Афганистана, включая и Хазараджат. Дискриминационная политика в отношении хазарейцев возобновилась: гражданское население уничтожалось физически, а пуштуны кучи вновь включили регион в свой ареал кочевок. Буддийские памятники, свидетельствующие об историческом прошлом хазарейского народа, осквернялись вандалами. Религиозные авторитеты движения «Талибан» объявили шиитский толк ислама ересью, а его последователей еретиками. Новый губернатор г. Мазари-Шарифа Мулла Манан Ниязи заявил, что всех шиитов города нужно обратить в суннизм, а несогласных предать смерти, либо изгнать за пределы страны (HRW 1998).

В результате международной операции «Несокрушимая свобода» в 2001 г. режим талибов пал. В постталибском Афганистане хазарейцы впервые были допущены к парламентским выборам и в 2005 г. заняли 30 из 249 мест в Национальной ассамблее (Wilder 2005: 8), а губернатором провинции Бамиан была назначена хазарейка Хабиба Сараби. Однако до настоящего времени доля представителей хазарейского народа в органах государственной власти Афганистана значительно меньше его доли в составе населения. В последнее десятилетие в стране участились направленные на хазарейцев террористические акты (похищения, убийства, взрывы), осуществляемые различными группировками региона. С терроризмом столкнулись и хазарейцы, проживающие в Пакистане (г. Квет), где уровень насилия в отношении шиитского меньшинства за последнее десятилетие вырос в разы (Olszewska 2013: 40-45).

Политические катаклизмы, сотрясающие страну последние 200 лет, привели к значительным изменениям в образе жизни и социальной организации хазарейского общества. Опыт жизни в Афганистане в качестве маргинализированного меньшин- 
ства наложил отпечаток и на стратегии выживания приехавших в Москву мигрантов-хазарейцев, предопределив особенности взаимодействия как внутри своей общины, так и с другими выходцами из Афганистана. Отношения основываются на тех же принципах, что и на родине: с пуштунами сохраняется дистанция, с узбеками, таджиками и иными малыми группами контакты могут носить более доверительный характер, изредка заключаются даже брачные союзы.

История взаимодействия хазарейцев с государством-завоевателем обусловила их стремление к сплочению своей группы, автономной, замкнутой жизни внутри общин и максимальному дистанцированию от властных структур. Прочность социальных связей между членами этого этнического сообщества зиждется на взаимной помощи и поддержке.

\section{Хазарейская община в Москве}

Эмиграция из Афганистана в конце $\boldsymbol{X} \boldsymbol{X}$ в. Среди афганцев, эмигрировавших в Россию в начале 1990-х годов, преобладали госслужащие (офицеры из ВС ДРА, службы госбезопасности [«ХАД»] и МВД [«Царандой»], партийные работники НДПА, инженерно-технические кадры) - это были главным образом пуштуны, таджики и узбеки. Иногда их именуют «кадровым запасом НДПА». В конце 1990-х годов представители «кадрового запаса», не нашедшие приюта в России, стали мигрировать в страны Европы и Америки. Поскольку члены хазарейской общины на протяжении XX в. были исключены из социальной и политической жизни афганского общества, среди московских хазарейцев практически не было людей, связанных в прошлом со службой в госструктурах ДРА (ПМА 2). Таким образом, переезд бывших сторонников НДПА в Россию, связанный с падением афганского просоветского режима, начался в 1992 г., а исход хазарейцев из Афганистана пришелся на вторую половину 1990-х годов. Многие информанты-хазарейцы говорили, что покинули свою страну из-за репрессивной политики движения «Талибан», поэтому они прибыли в Москву уже после 1997 г. (ПМА 1).

Социальные стратегии эмигрантов. Сами московские хазарейцы условно выделяют в своей среде три категории эмигрантов. Первая (немногочисленная) - студенты, приехавшие учиться еще в СССР. После обучения они остались в России, обзавелись семьями, причем иногда брали в жены русских девушек (россиянок). Вторая - приехавшие в Москву в 1990-2000-е годы с конкретной целью - заниматься бизнесом. Чаще всего это была оптовая торговля товарами широкого потребления из КНР и Турции. Эта категория активно использовала родственные сети: люди приезжали на уже «освоенное» место, включались в уже имеющийся бизнес, а затем, накопив необходимую сумму, открывали свое дело. Третью группу составляют те, кто планировал, занимаясь бизнесом, заработать деньги и эмигрировать в страны Европы и Америки, но по каким-либо причинам остался в Москве (ПМА 2). Эта категория хазарейцев активно использовала родственные связи как в Москве, так и в стране, куда планировался переезд.

Научных исследований, касающихся выходцев из Афганистана, обосновавшихся в Москве, почти не проводилось. Можно назвать лишь статью В.Д. Попкова «Сообщество афганских мигрантов в Москве: вопросы структуры и идентичности» (Попков 2003). Некоторые выводы автора справедливы и сегодня. Так, он пишет: 
«Афганское сообщество, или сообщества представляют собой сетевую структуру, с сетевой линейной организацией и множеством ячеек, с неявно выраженным лидерством» (Там же 2003: 150). У хазарейцев доминирует в первую очередь этническая, клановая, региональная, а затем уже общеафганская идентичность (Там же 2003: 157). Добавим, что в сохранении стойкой этнической идентичности важную роль играет религиозная самоидентификация (шиизм). Показательно, что представители изучаемой группы могут называть остальных соотечественников «афганцами», но себя только «хазарейцами». То есть хазарейцы дистанцируются от других выходцев из Афганистана, их собственная этническая идентичность превалирует над гражданской. В исследовании 2003 г. хазарейская община отмечена как более сплоченная по сравнению с иными афганскими общинами Москвы (Там же 2003: 159). Как будет показано ниже, этот вывод справедлив и в настоящее время. Точных данных о нынешней численности хазарейцев в Москве нет, так как многие люди старшего поколения, приехавшие в 1990-е годы, успели получить российское гражданство. По оценкам самих информантов, число постоянно проживающих в столице РФ хазарейцев составляет примерно 1500-2000 человек.

Как и многие другие выходцы из Афганистана, хазарейцы в большинстве своем занимаются торговлей. Им принадлежат торговые точки на юге и юго-востоке Москвы в торговых комплексах «Садовод», «Москва», «Люблино», «Южные ворота». Чаще всего это крупно- и мелкооптовые продажи одежды, обуви и аксессуаров (зонтиков и сумок) китайского производства, кожаных курток из Пакистана и т.п. Некоторые хазарейские предприниматели владеют фирмами, занимающимися организацией доставки товаров из КНР; в логистической цепочке, как и торговых делах, задействованы многоуровневые связи - родственные, клановые, общеафганские. Как говорят многие информанты, «в бизнесе должны быть все свои» (ПМА 1), поэтому работники обычно набираются по родственному принципу - из уже живущих в столице РФ и из прибывающих из Афганистана.

По словам информантов, большинство хазарейцев Москвы - из каума Туркман, но есть также представители каумов Бесуди и Джагури (ПМА 5). Для старшего поколения клановые и трайбалистские структуры сохраняют свою значимость, для молодых людей - приехавших из Афганистана студентов или же юношей и девушек, родившихся и выросших в Москве - они уже не существенны. Наоборот, в таком делении они видят главное препятствие, мешающее консолидации и развитию хазарейцев как единого народа. Более того, политические взгляды хазарейцев старшего поколения (среди них встречаются и бывшие коммунисты, и сторонники или сочувствующие в прошлом НДПА, и «моджахеды» - так иногда именуют сторонников партии «Хезб-э Вахдат») уже не являются разъединяющими факторами, как это было раньше. Этническая принадлежность также перестает быть препятствием для общения. К примеру, среди пожилых хазарейцев есть небольшое число коммунистов, которые иногда собираются вместе с бывшими членами НДПА других национальностей. Так, по словам информантов, весной 2020 г. «коммунисты» отмечали день Бабрака Кармаля 1 , арендовав под свое мероприятие кафе. Бизнесмены из числа «коммунистов» вместе с другими членами хазарейской общины жертвуют деньги на проведение различных

\footnotetext{
${ }^{1}$ Бабра́к Карма́ль - афганский политический, государственный и партийный деятель, один из основателей НДПА, лидер фракции «Парчам» («Знамя»), Генеральный секретарь ЦК НДПА (1979-1986 гг.). После отставки жил в Москве до своей смерти в 1996 г.
} 
религиозных мероприятий и принимают участие в них. «Политические пристрастия прошлого остались в прошлом, нет теперь ни “коммунистов”, ни “моджахедов”, ни противостояний между ними, теперь есть только хазара» (ПМА 2).

Отношения с другими шиитскими общинами. Несмотря на то что религия исключительно важна для хазарейцев, религиозная идентичность, как правило, вторична по отношению к идентичности этнической. Религиозная жизнь хазарейцев во многом проходит изолированно от жизни других общин, исповедующих шиизм. Тем не менее с азербайджанцами поддерживаются некоторые контакты; иногда проводятся совместные церемонии в московских хусайния $x^{1}$, при этом часто возникает вопрос: какой язык следует использовать? Азербайджанские маджлисы ведутся на азербайджанском, хазарейские - на дари, и хотя большая часть прихожан знает русский язык, он принципиально не используется на религиозных мероприятиях.

Иногда члены хазарейской общины приглашаются на религиозные мероприятия, которые организуются иранцами, проживающими в Москве. Обычно такие маджлисы проходят в мечети при посольстве Ирана. Хазарейцы старшего поколения относятся к иранскому государству с одобрением или нейтрально, молодежь часто высказывает недовольство тем, что Иран стремится, используя религиозные инструменты, навязывать свою внешнюю политику, направленную на конфронтацию с США и странами Европы, и не принимает во внимание нужды и запросы хазарейцев Афганистана. Кроме того, в самом Иране многие хазарейцы из числа беженцев и мигрантов оказываются «людьми второго сорта»: афганские документы хазарейцев зачастую не признаются, людям отказывают в предоставлении иранского гражданства, соответственно, они не могут работать официально (Feroz 2014). Помимо этого, как говорят информанты, поддержка иранской политики стоила жизни многим хазарейцам в Афганистане в годы войны. Так, в Сирии, как на стороне режима президента Башара Асада, так и на стороне его противников, воюют различные «прокси-армии». Одно из формирований, сражавшихся на стороне Асада, - «Лива Фатимийюн» («Бригада Фатимы») состояло из хазарейцев, оно было создано при активном содействии и поддержке иранского Корпуса стражей Исламской революции (КСИР). Иранское командование использовало «Лива Фатимийюн» на самых опасных участках фронта, поэтому Бригада понесла большие потери (Кириченко 2019). КСИР привлекает в военные формирования безработных хазарейцев из Ирана или Афганистана, обещая денежное вознаграждение и поддержку семьям «добровольцев» в случае их гибели (Fighting for Asad 2016).

Семейные традиции и брачные контакты. Информанты подчеркивают важность следования устоявшимся традициям в семейной сфере; брачные связи укрепляют отношения между родственными группами и кланами. Для хазарейцев Афганистана, как и для других этнических групп страны, характерны эндогамные браки. В Москве и в России в целом им иногда трудно найти подходящего брачного партнера ввиду малочисленности их этнической группы, поэтому в поисках невесты или жениха часто задействуются связи в самом Афганистане. «Вторую половину» часто подбирают на исторической родине, свадебные церемонии проводятся там же, после чего молодожены приезжают в Россию. Такой сценарий характерен для большинства мужчин хазарейцев, живущих в Москве. Помимо расходов на свадебные мероприятия, жених

\footnotetext{
${ }^{1}$ Хусайнийа («дом Хусейна») - место для проведения церемоний, связанных с шиитским религиозным календарем.
} 
и его родственники оплачивают переезд супруги и оформление всех необходимых документов, включая визу и регистрацию по новому месту жительства. Изредка хазарейцы мужчины берут в жены представительниц других этнических групп Афганистана, проживающих в России, - таджичек или узбечек; очень редки браки с русскими девушками - родители жениха чаще всего осуждают такой выбор.

По словам информантов, некоторые хазарейцы в поисках будущего мужа для своих дочерей обращаются к родственникам, эмигрировавшим в страны Европы или Америки, поскольку, выйдя замуж, девушка получает гражданство той страны, где проживает ее супруг. Иногда мужей ищут среди хазарейцев, обосновавшихся в России. Информанты, имеющие дочерей, говорили, что единственным критерием для будущего супруга является его религиозная принадлежность (исповедование ислама). Один из информантов собирается найти мужа для своей дочери в среде хазарейцев Афганистана, причем он готов взять на себя все расходы, связанные с поиском жениха и его переездом в Россию.

В семьях выходцев из Афганистана, проживающих в Москве, в том числе и в семьях хазарейцев, во многом воспроизводятся характерные для страны исхода сценарии, связанные с распределением функций супругов. На мужчину ложатся обязанности по содержанию семьи, своих родителей и других родственников, проживающих в Афганистане. Абсолютное большинство жен московских хазарейцев не работает, они занимаются воспитанием детей и домашним хозяйством (ПМА 4). Близкие родственники многих наших информантов остаются в Афганистане и категорически отказываются от переезда в Россию. Поэтому мужчины должны не только обеспечивать себя и свои семьи, но и поддерживать родню, оставшуюся на родине. Справляться с финансовыми проблемами позволяет довольно прибыльное и в то же время рискованное занятие торговлей.

Роль предпринимателей в общине. Хазарейские предприниматели входят в органы коллективного руководства своей общины в Москве и выступают главными спонсорами любых религиозных и национальных мероприятий. Решения внутри общины принимаются группой авторитетных членов (в отличие от пуштунов, «центры» которых возглавляются конкретным общепризнанным лидером; в качестве примера можно привести «Центр диаспор Афганистана», разместившийся в ТЦ «Севастополь»). Многие хазарейцы подчеркивают, что схожая с их собственной система самоорганизации наблюдается и у афганских таджиков (ПМА 3).

Студенческая ассоциация хазарейцев «Катиб» представляет собой пример такой самоорганизующейся структуры. Она сформировалась на основе принципов традиционного самоуправления с присущими ей механизмами взаимопомощи и поддержки членов общины и опирается на собственные ресурсы.

\section{Студенческая научно-культурная ассоциация «Катиб» в РФ}

Ассоциация «Катиб», зародившаяся в Москве в 2016 г., представляет собой сетевую самовоспроизводящуюся организацию студентов-хазарейцев из Афганистана. Ее основная задача - помощь хазарейцам, обучающимся в России. Приблизительная численность «Катиб» на 2020 г. составила около 100 человек. Ассоциация названа в честь афганского придворного летописца и секретаря при эмире Хабибулле-хане (1901-1919), автора работ по истории Афганистана, Фаиза Мохаммада Катиба Хаза- 
pa (1860-1931) (Fayz Muhammad 1998). Фаиз Мохаммад Катиб - своего рода символ национальной гордости хазарейцев, его образ ассоциируется с плодами образования и учености, благодаря которым Катиб добился признания во враждебном к хазарейцам «афганском государстве». Многие общественные и культурные организации, созданные представителями хазарейской общины в странах Европы, Северной Америки и в Австралии, носят его имя.

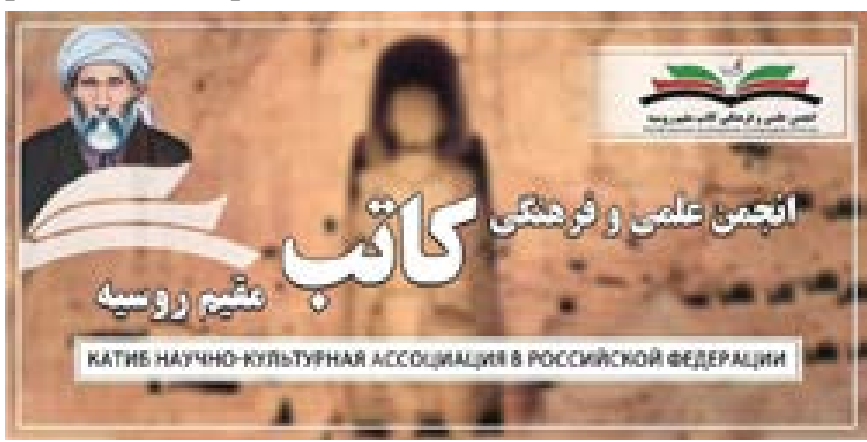

Рис. 1. Логотип студенческой ассоџиаџии «Катиб».

Во главе ассоциации «Катиб» в РФ стоят руководитель и четыре заместителя. Ротация людей, занимающих эти должности, происходит ежегодно - свою кандидатуру может выдвинуть любой студент хазарейской национальности, представив краткую программу развития ассоциации. Выборы проходят на общем собрании студентов, о чем всех оповещают в мессенджерах. В обязанность руководителя входит координация деятельности членов ассоциации и взаимодействие со спонсорами - живущими в Москве хазарейцами-предпринимателями. Заместители возглавляют «департаменты»: культурный, экономический, женский и спортивный. У ассоциации нет своих помещений, собрания проходят в различных местах. Пару лет назад предлагалось организовать офис «Катиб» в ТЦ «Севастополь», где работает много выходцев из Афганистана и располагается общественная организация «Центр диаспор Афганистана». Но руководство ассоциации отказалось от этой идеи по ряду причин, которые будут описаны ниже. Официального статуса у ассоциации пока нет, ее регистрация не является приоритетом для членов «Катиб». Пандемия и последующий карантин весной 2020 г. отразились на проведении выборов нового главы «Катиб» и его заместителей. Часть студентов в марте 2020 г. улетела на родину в Афганистан и не смогла вернуться обратно в Москву. На момент написания статьи (ноябрь 2020 г.) выборы так и не состоялись.

Включение студентов в ассоциацию. Главный критерий членства в ассоциации «Катиб» - этническая принадлежность, поскольку, как было указанно ранее, организация создавалась для поддержки хазарейских студентов, обучающихся в Москве.

Ротационный механизм «воспроизводства» ассоциации достаточно прост: «старшие» члены «Катиб», оказывая помощь вновь прибывшим студентам, не знающим ни русского языка, ни порядка действий, связанных с размещением и включением в студенческую жизнь в Москве, передают им своего рода «эстафету». Через некоторое время «новички» заменяют «старичков», уезжающих на родину после окончания учебы. Так выстраивается устойчивая внутренняя система. Поскольку часть студентов отправляется на учебу в другие города России и помощь им требуется уже «на месте», ассоциация строится по сетевому принципу.

Прибывающих студентов, у которых нет знакомых в России, сразу видно: они не знают русского языка, их никто не встречает. Мы (члены ассоциации «Катиб». - Э.С.) обычно отслеживаем рейсы из Афганистана в Москву, дежуря в аэропортах по очереди, заранее покупаем сим-карты для мобильных теле- 
фонов, раздаем их бесплатно вновь прибывшим, чтобы иметь связь с ними, переписываем их данные и отправляем в другие города, где у нас есть члены ассоциации, если студент учится в другом городе России. Если он учится в Москве, то помогаем ему с размещением в общежитии, в заполнении различных документов на русском (ПМА 3).

Подобная помощь может быть оказана и студентам из числа других этнических групп Афганистана, но без включения их в структуру ассоциации.

Культурная деятельность наиболее заметное и важное направление работы «Катиб», основная цель которого - способствовать этнической консолидации московских хазарейцев. Кроме того, ассоциация проводит (параллельно с национальными общинами, проживающими в различных частях мира) мероприятия, имеющие общехазарейский статус: «Международный день солидарности хазарейского народа» и «День памяти (мученической смерти) Абдул Али Мазари».

«День солидарности» отмечается 1 октября, день коммеморации появился менее десяти лет назад, он призван привлечь внимание мировой общественности к положению хазарейцев в Афганистане и Пакистане. В Москве в 2019 г. это мероприятие было проведено 10 ноября в арендованном помещении ресторана «Бакинский бульвар» близ ТК «Южные ворота». Помимо хазарейцев (около 150-200 человек) на нем присутствовали несколько приглашенных студентов и преподавателей ИСАА МГУ. Официальная часть состояла из выступлений членов ассоциации, затем был концерт, а в завершении - банкет. Зал ресторана был украшен символами, отсылающими к коллективной памяти хазарейцев: на кафедре с микрофоном был установлен портрет национального героя Абдул Али Мазари, рядом размещен флаг Хазаристана, имеющий неофициальный статус «национального флага Хазараджата». Слева от сцены была организована импровизированная выставка книг по истории и культуре хазарейцев на языке дари. (Исследования

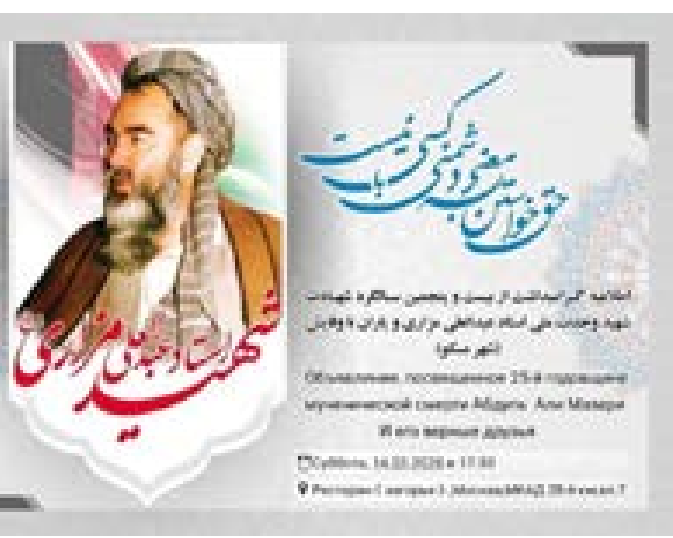

Рис. 2. Пригласительный билет на мероприятие посвященное 25-й годовщине гибели национального хазарейского лидера Абдул Али Мазари (Баба Мазари) в Москве.

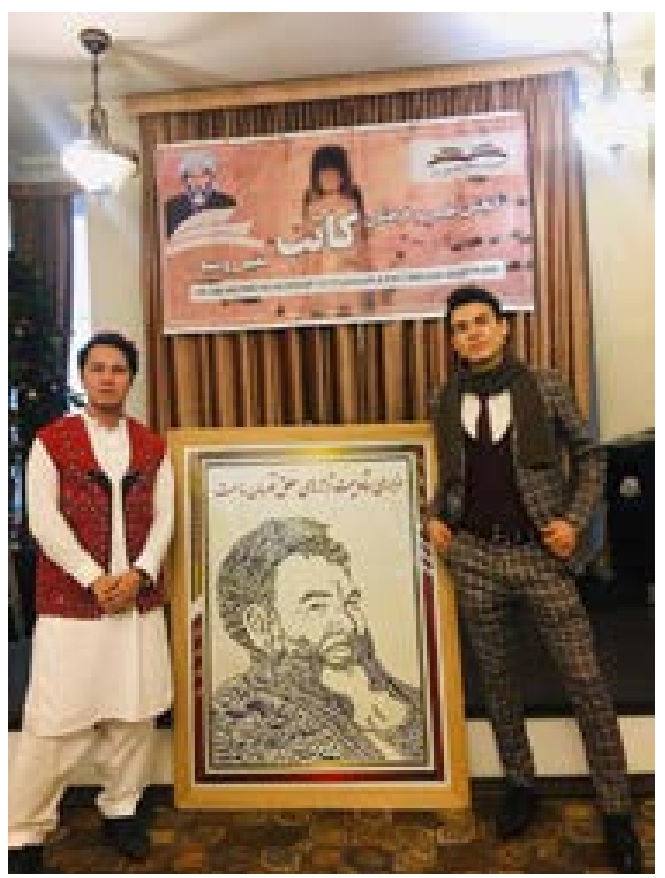

Рис. 3. Члены ассоџиаџии «Катиб» на мероприятии «День солидарности хазарейского народа».(Рис. пресс службы ассочиащии «Катиб»). 
истории и культуры народа подтверждают автохтонность происхождения хазарейцев, опровергая распространенное представление об их происхождении от монгольских завоевателей Афганистана.) На баннере ассоциации «Катиб», висевшем над сценой, располагались изображения Фаиза Мохаммада Катиба и статуи Будды в Бамиане - два особо значимых для хазарейцев символа.

Необходимость единства всех хазарейцев, вне зависимости от их родоплеменной и территориальной принадлежности, политических и конфессиональных предпочтений, была образно подчеркнута небольшим театрализованным представлением, подготовленным членами ассоциации «Катиб». Пять участников действа вышли на сцену с буквами на груди, составлявшими слово «хазара» (на арабице). Отдельные буквы символизировали различные каумы, а сборный домик, стоявший на сцене, - Хазараджат. Один из участников сценки играл роль «заклятого врага» хазарейского народа Абдур Рахман Хана, он пытался разорвать цепь крепко держащихся друг за друга «каумов» (разбить единство хазарейцев). После неудачи «Абдур Рахман Хан» решил действовать по-другому: он подговаривает одного за другим все «каумы», шепча им что-то на ухо, и «каумы» начинают забирать части домика (крышу, стены) и расходиться в разные стороны. Но, постояв и подумав, «каумы» возвращаются и вновь строят общий дом.

«День памяти Абул Али Мазари (“Баба Мазари”)», боровшегося за права своего народа хазарейского лидера, погибшего от рук талибов 15 марта 1995 г. и после смерти приобретшего образ мученика, превратился для проживающих в различных регионах мира хазарейцев в общенациональное событие. В самом Афганистане мероприятия в День памяти «Баба Мазари» зачастую подвергаются террористическим атакам со стороны талибов или других организаций. Так, в начале марта 2020 г. В Кабуле во время мемориальной церемонии, посвященной 25 годовщине гибели Али Мазари, на которой присутствовал премьер-министр Афганистана Абдула Абдулла, был совершен теракт - его жертвами стали более 100 человек (ВВС 2020). В Москве День памяти Али Мазари проводится хазарейцами ежегодно в марте уже более 15 лет. Раньше арендовались небольшие кафе, но с увеличением московской общины в последнее десятилетие мероприятия проводятся в большом банкетном зале «За-

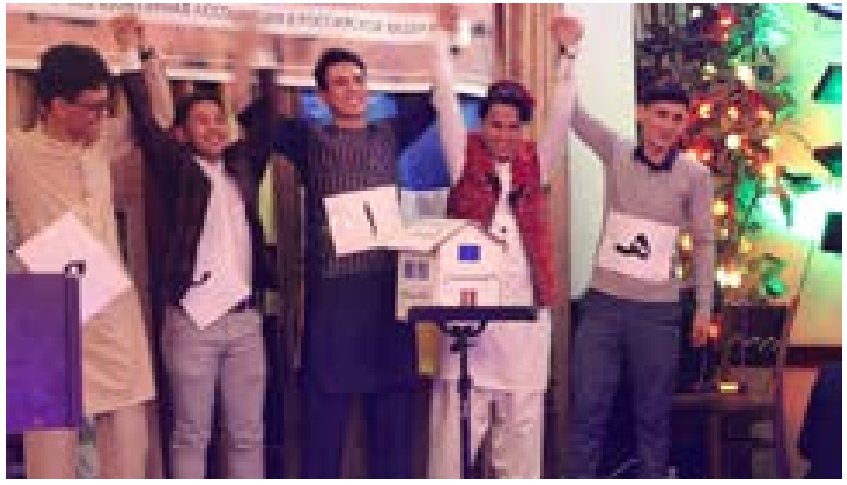

Рис. 4. Сиенка показанная на мероприятии «День солидарности хазарейского народа». Буквы прикрепленные к одежде участников образуют слово «Хазора»(Хазара). Надпись на фронтальной части домика «Бамийон»(Бамиан). (Рис. пресс службы ассоџиаџии «Катиб»). горье». В 2020 г. День памяти Абдул Али Мазари прошел 14 марта и собрал от 700 до 800 человек. Помещение было украшено баннерами с изображениями Абдула Али Мазари и погибших вместе с ним членов партии «Вахдат», над импровизированной сценой висел национальный афганский флаг это подчеркивало значимость личности Абдул Али Мазари для всего Афганистана.

Расходы, связанные с проведением этих мероприятий (аренда помещений, угощение, изготовление баннеров и пр. 
для оформления залов), полностью взяли на себя хазарейские предприниматели. Роль членов «Катиб» заключалась в составлении сценариев, украшении помещений, распространении приглашений. Кроме того, члены ассоциации встречали и размещали гостей, а также выступали в роли ведущих.

Используемые образы и символы, исторические паттерны, понятные хазарейцам в любой точке мира, поддерживают чувство принадлежности к «хазарейской нации», нивелируя трайбалистские и конфессиональные различия.

Одно из направлений деятельности «департамента» культуры ассоциации может быть обозначено как «наука и образование». Членами «Катиб» научная деятельность рассматривается как один из основных способов, позволяющих привлечь внимание к ситуации в современном Афганистане, высказать свою точку зрения либо выступить от лица хазарейского сообщества в академических кругах. В 2019 г. многие члены ассоциации представили свои доклады на Международной студенческой научной конференции «100-летие независимости Афганистана и 100-летие установления дипломатических отношений между Афганистаном и Россией», прошедшей в ИСАА МГУ 25 октября. Кроме того, на странице ассоциации в Фейсбуке публикуются статьи хазарейских студентов на языке дари с различной тематикой: посвященные как анализу различных событий и в целом ситуации в Афганистане, так и реакции на происходящее в мире.

Образовательная деятельность ассоциации заключается в проведении неформальных уроков для хазарейцев, родившихся или выросших в Москве. Обучение родному языку, истории своего народа этих молодых людей происходит через включение их в круг общения членов «Катиб»; часто такие встречи проходят в неформальной обстановке.

Экономическое направление. Экономический «департамент» оказывает безвозмездную разовую финансовую помощь нуждающимся хазарейским студентам как в Москве, так и в других городах России. Помощь может быть адресована студентам и в самом Афганистане, а также их родственникам. Те, кому необходима денежная поддержка, связываются через мессенджеры с главой ассоциации, после чего составляются списки, и людям на карту отправляются определенные суммы. Во время весеннего карантина из-за распространения COVID-19 была оказана разовая помощь более чем 20 хазарейским студентам в различных городах России. Финансируется деятельность ассоциации, как уже отмечалось выше, хазарейскими предпринимателями, которые переводят средства на счет главы «Катиб», а глава распределяет их по «департаментам».

Московскими хазарейцами используется и такая форма поддержки, как коллективная экономическая помощь. К ней прибегают, например, если необходимо организовать сбор средств для отправки тел умерших членов общины из Москвы в Афганистан. Хазарейцы желают быть похороненными на родине, поближе к своим родным. В сборе денег принимают участие и предприниматели по мере возможностей: «Кто-то $100 \$$ даст, а кто и 1000 может дать... во время карантина умер один хазареец, и отправка тела в Афганистан обошлась около 6000 \$, все это оплатили наши бизнесмены» (ПМА 3).

«Женское» направление. Положение женщин в Афганистане - тема очень актуальная и болезненная для членов ассоциации. Подчеркивая важность женщин в хазарей- 
ском и афганском обществах, информанты-юноши приводят высказывание Абдул Али Мазари о том, «что женщины - это половина силы нашей нации, они равны нам, мужчинам, но их роль гораздо важнее, они воспитывают нацию, они наши матери, сестры, жены» (ПМА 3). Во главе «женского департамента» стоит избираемая на год девушка, отвечающая за организацию совместной работы студенток, решение бытовых вопросов, проведение коллективного досуга и включение в сообщество русскоязычных хазареек. Для девушек актуальна проблема поиска подходящей работы, поскольку в отличие от парней они не могут трудиться в определенных сферах. Это связано как с афганскими морально-этическими нормами поведения для незамужних девушек, так и с недостатком вакансий, удовлетворяющих этим нормам (ПМА 3, 4). Для поддержки девушек многие хазарейские предприниматели нанимают их в качестве воспитательниц и домашних учительниц для своих детей. Студентки несколько раз в неделю проводят занятия по английскому и родному языкам, математике и т.д. (ПМА 3).

Спортивное направление. Спортивные мероприятия - важный инструмент коммуникации и установления прочных взаимоотношений между «старыми» и «новыми» членами ассоциации. У «Катиб» есть своя футбольная команда, она состоит из парней - членов ассоциации, девушки по понятным причинам не привлекаются. В играх иногда принимают участие хазарейские предприниматели, часто проводятся встречи с московскими студенческими командами, что способствует налаживанию дружеских отношений с российской молодежью.

В проведении мероприятий, не имеющих статуса религиозных или национальных, принимают участие все «департаменты» ассоциации. Примером может служить организация банкета после победы в Москве афганского бойца ММА. Бой хазарейца Хусейна Бахша, выходца из провинции Бамиан, с россиянином Петром Бергом состоялся 29 декабря 2019 г. (MENAFN 2019). 30 декабря был организован банкет с приглашением самого афганского бойца и вручением ему подарков от лица хазарейских предпринимателей. Многими информантами эта победа воспринимается как «спортивная победа всего народа Афганистана, объединяющая всех жителей страны, когда можно забыть об этнических и конфессиональных различиях» (ПМА 3). Расходы, связанные с приездом Хусейна Бахша в Москву, его размещением и праздничными мероприятиями в честь его победы, взяли на себя хазарейские предприниматели. Инициатива по проведению боя в Москве принадлежала ассоциации «Катиб», ее члены отвечали за встречу в аэропорту афганского спортсмена и помогали в организации банкета.

Отношения «Катиб» с другими общественными организациями выходцев из Афганистана часто повторяют межэтнические взаимодействия, характерные для страны исхода. У ассоциации установлены хорошие контакты со студенческими союзами афганских таджиков: совместно организуется и проводится празднование Навруза на ВДНХ. Сложилась практика взаимопосещения национальных мероприятий, дней памяти национальных лидеров: таджики приглашаются на дни памяти Али Мазари, а хазарейцы - студенты и предприниматели - принимают участие в днях памяти лидера таджиков Афганистана Ахмад Шаха Масуда. Хорошим контактам способствуют союзнические отношения в прошлом между политическими и военными организациями таджиков и хазарейцев в самом Афганистане.

С пуштунскими организациями или с теми, где у руководства стоят пуштуны, никаких совместных мероприятий нет. Информанты объясняют это тем, что «Центр диаспор Афганистана» во главе с господином Гуламом Мохаммадом Джалалом, пушту- 
ном по национальности, позиционирует себя (в том числе в отношениях с российской стороной) как главную организацию, объединяющую всех выходцев из Афганистана в Москве. По словам информантов, Центр пытается реализовать свою «политику», навязывая другим объединениям афганцев принятые им решения, настаивая на выделении средств предпринимателями для проведения организованных им мероприятий, лишая права голоса остальные ассоциации в решении внутренних афганских вопросов. Все это расходится с интересами членов «Катиб» и хазарейских предпринимателей. Налицо различие в управлении различными афганскими общинами в Москве: коллективное руководство у хазарейцев и единоначалие у пуштунов. В качестве гипотезы можно предположить, что причины взаимного недоверия и отчуждения кроются в том, что у хазарейцев и таджиков в Афганистане нет жесткой родоплеменной иерархии, в отличие от пуштунов, у которых роды возглавляются вождями - маликами (Akbar 1976: 173-175), и в том, что различные подходы в управлении этническими общинами в самом Афганистане воспроизводятся и за его пределами.

Отношения ассоциации «Катиб» и посольства Афганистана характеризуются минимумом контактов. Посол и дипломатические работники не посещают мероприятия, организованные хазарейской стороной, а представители хазарейской общины очень редко (и очень немногие) приглашаются посольством на свои торжественные мероприятия. К примеру, на вечер в честь

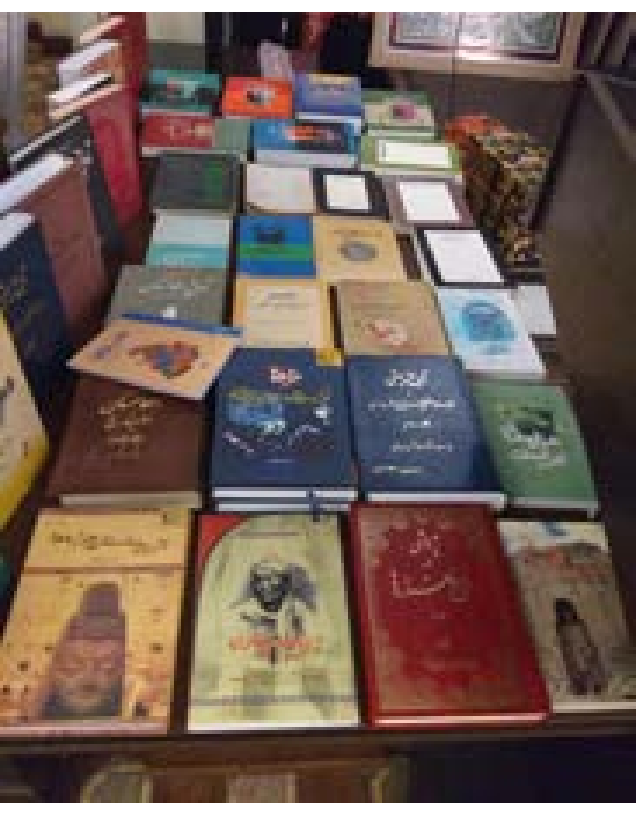

Рис. 5. Книги на дари по истории хазарейцев, мероприятие "День солидарности хазарейского народа» (фото автора). 100-летней годовщины провозглашения независимости Афганистана, организованный посольством в Культурном центре ГлавУпДК при МИД РФ 21 августа 2019 г., на котором присутствовало большое количество гостей, дипломатов, атташе из различных стран, были приглашены всего лишь три московских хазарейца. Впрочем, это не мешает посольству Афганистана часто обращаться к хазарейским предпринимателям с просьбой оказать финансовую помощь в проведении национальных праздников в Москве. Напрашивается аналогия с положением хазарейской общины в Афганистане в XX в., когда хазарейцы не только были исключены из общественной и социальной жизни афганского общества, но и обложены афганскими властями высокими денежными поборами.

1. Внутренняя самоорганизация и автономный статус хазарейской общины в Москве отсылают нас к историческому опыту народа. На протяжении XIX-XX вв. представители этой этнической группы неоднократно подвергались дискриминации и насилию со стороны «афганского государства», особенно во время правления Абдур Рахман Хана и в «талибский» период. 
2. Вследствие такого исторического опыта хазарейские общины превратились в автономные сообщества, опирающиеся на собственные ресурсы и минимизировавшие контакты с государством в решении различных вопросов. Московский пример, рассмотренный в статье, не уникален, он повторяет практику функционирования других хазарейских общин за пределами Афганистана. Можно привести в качестве подтверждения исследование А. Монсутти, в котором автор анализирует проведение хазарейцами, проживающими в г. Квета в Пакистане, религиозных мероприятий в месяц мухаррам: для организации траурных церемоний используются средства, собранные членами общины, объединенными в калан-э каум (большой каум) или в калан-э махалла (большую общину). Коллективный сбор средств используется также и для помощи как вновь прибывшим в Пакистан членам общины (на покупку дома или земельного участка, на прочие расходы), так и нуждающимся хазарейцам в самом Афганистане. В сборе денежных средств участвуют по мере возможности все члены общины - таким образом формируется своего рода «касса взаимопомощи» (Monsutti 2007: 179-183).

3. Важно учитывать мотивацию предпринимателей, активно финансирующих ассоциацию «Катиб» в Москве. Долгое время (на протяжении всего XX в.) хазарейцы были исключены из системы высшего государственного образования, и помощь студентам рассматривается бизнесменами как вклад в поднятие статуса хазарейской общины в афганском обществе.

4. Отсутствие одного лидера и коллективное руководство общиной также во многом объясняется историческим опытом. Это результат лишения сейидов и мир в 80-е годы ХХ в. статуса «традиционных лидеров» и прихода «новых лидеров»- выдвинувшихся за счет своих личных качеств в ходе гражданской войны. Новые руководители использовали новые методы консолидации, а в некоторых случаях опирались на иностранную финансовую помощь. Но наиболее важная причина, на которую следует обратить особое внимание, заключается в том, что после завоевания Хазараджата в конце XIX в. и последующей трансформации хазарейской традиционной родоплеменной структуры (каумы) управление внутренними делами некоторых общин осуществлялось на основе коллективного руководства, а не только сейидами - социальными авторитетами, сохранившими свою значимость. В настоящее время и у московских хазарейцев, и в хазарейском обществе Афганистана статус сейидов низок. Во многом утрата прежнего высокого положения сейидов в хазарейской общине сходна с утратой своего статуса суфийскими авторитетами в новейший период страны. Р.Р. Сикоев в статье, посвященной влиянию суфийских орденов на социально-политическую жизнь Афганистана, видит причины такого положения дел в следующем:

...до войны местное население получало от них (суфийских авторитетов. Э.С.) информацию, которая позволяла ориентироваться в меняющихся условиях жизни. Однако война, политические коллизии, иностранное вмешательство породили такие условия, в которых, например, суфии-отшельники уже не могли разбираться и тем более давать советы и наставления своим послушникам (Сикоев 2005: 384).

Многие сейиды в годы гражданской войны заняли либо проиранскую позицию, либо отстаивали собственные интересы, ставя их выше национальных, хазарейских, что немало способствовало утере ими высокого в прошлом уровня доверия. 


\section{Благодарности}

Автор выражает благодарность членам «Студенческой научно-культурной ассоциации “Катиб” в РФ», а также хазарейским предпринимателям, согласившимся дать интервью в рамках исследования.

\section{Источники и материалы}

Бартольд 1903 - Бартольд В.В. Историко-географический обзор Ирана. СПб., 1903.

ПМА 1 - Полевые материалы автора. Информант А.А., 45 лет, хазареец, предприниматель, проживает в Москве с 1998 г., имеет ВНЖ в России.

ПМА 2 - Полевые материалы автора. Информант О.Х., 50 лет, хазареец, предприниматель, проживает в Москве с 1997 г.

ПМА 3 - Полевые материалы автора. Информант Ф., 24 года, хазареец, студент, глава ассоциации «Катиб» 2019-2020 гг.

ПМА 4 - Полевые материалы автора. Информант С., 24 года, хазареец, студент, учится в Москве с 2017 г.

ПМА 5 - Полевые материалы автора. Информант Ш, 25 лет, хазареец, студент, учится в Москве с 2017 г.

Туркман 1916- Туркман И. Тарих-и аламара-йи Аббаси. Тегеран, 1916.

BBC 2020 - BBC news. Kabul Attack: Abdallah Abdullah Escapes Deadly Attack. 06.03.2020. https://www.bbc.com/news/world-asia-51766602

Bellew 1879 - Bellew H.W. Afghanistan and Afghans. L., 1879.

Bellew 1880 - Bellew H.W. The Races of Afghanistan, Being a Brief Account of the Principal Nation. Calcutta, 1880.

Feroz 2014 - Feroz E. Treated Like Second-Class Citizens. Qantara.de. 2014. https://en.qantara. de/content/afghan-refugeed-in-iran-threated-like-second-class-citizens (дата обращения: 24.10.2020).

Fighting for Asad 2016 - Fighting for Asad: Iran's Foreign Legion // YouTube. 07.06.2016. https:// youtu.be/WESjWZ0BzLA

HRW 1998 - Afghanistan: The Massacre in Mazar-e Sharif. N.Y.: Human Rights Watch, 1998.

HRW 2005 - Blood Stained Hands: Past Atrocities in Kabul and Afghanistan's Legacy of Impunity. N.Y.: Human Rights Watch, 2005.

Khan 1900 - Khan A. (ed.) The Life of Adbur Rahman Khan, The Amir of Afghanist. L.: John Murray, 1900.

MENAFN 2019 - Young Afghan MMA Fighter Defeats His Russian Rival in a Breathtaking Fight // MENAFN. 29.12.2019. https://menafn.com/1099482670/Young-Afgan-MMA-fighter-defeathis-Russian-rival-in-a-breathaking-fight

\section{Научная литература}

Кириченко В.П. Участие хазарейцев Афганистана в сирийском конфликте // Россия и мусульманский мир, 2019. № 4 (314). С. 70-78.

Кисляков B.Н. Хазарейцы, аймаки, моголы (к вопросу об их происхождении и расселении) // Советская этнография, 1973. № 4. С. 130-139.

Коргун В.Г. Ислам и проблемы развития Афганистана // Ислам и общественное развитие в начале XXI века / Отв. ред. В.Я. Белокреницкий, А.З. Егорин, Н.Ю. Ульченко. М.: Крафт, 2005. C. $141-151$.

Петрушевский И.П. Земледелие и аграрные отношения в Иране XIII-XIV веков. М.; Л.: Издво АН СССР, 1960.

Попков В.Д. Сообщество афганских мигрантов в Москве: вопросы структуры и идентичности // Журнал социологии и социальной антропологии, 2003. T. VI. № 2. С. 150-164. 
Сикоев Р.P. Суфийские ордены в социально-политической жизни Афганистана // Ислам и общественное развитие в начале XX века / Отв. ред. В.Я. Белокреницкий, А.З. Егорин, Н.Ю. Ульченко. М.: Крафт, 2005. С. 376-385.

Темирханов Л. Хазарейцы (очерки новой истории). М.: Наука, 1972.

Akbar S.A. Millennium and Charisma among Pathans: A Critical Essay in Social Anthropology. L.: Routledge; Kegan Paul, 1976.

Canfield R. Hazara Integration into the Afghan State: Some Changing Relations between Hazaras and Afghan Officials. N.Y.: The Afghanistan Council, 1972.

Emadi H. Exploring Iran's Revolution: The Radicalization of the Shiite Movement in Afghanistan // Middle Eastern Studies, 1995. Vol. 31 (1). P. 1-12.

Fayz Muhammad. Kabul Under Siege: Fayz Muhammad's Account of the 1929 Uprising / Transl. R.D. McChesney. Princeton: Markus Wiener Publishers, 1998.

Ferdinand K. Preliminary Notes on Hazara Culture (The Danish Scientific Mission to Afghanistan (1953-1955). Kobenhavn: Ejnar Munksgaard, 1959.

Ferdinand K. Nomad Expansion and Commerce in Central Afghanistan. Vol. 4. Kobenhavn: Folk, 1962.

Harpviken B.K. Political Mobilization among the Hazara of Afghanistan: 1978-1992. Oslo: Departament of Sociology University of Oslo, 1996.

Husseini S.R. Destruction of Bamiyan Buddhas: Taliban Iconoclasm and Hazara Response // Himalayan and Central Asian Studies. 2012. Vol. 16. No. 2. P. 15-50.

Ibrahimi N. The Hazaras and the Afghan State: Rebellion, Exclusion and the Struggle for Recognition. L.: HURST\&COMPANY, 2017.

Laali A. Sairey dar Hazarajat. Qom: Ehsani, 1993.

Minahan J.B. Ethic Groups of North, East, and Central Asia. Santa Barbara: ABC-CLIO, 2014.

Monsutti A. Image of the Self, Image of the Other: Social Organization and the Role of "Ashura" among the Hazaras of Quetta (Pakistan) // The Other Shiites: From the Mediterranean to Central Asia / Eds. A. Monsutti, S. Naef, F. Sabahi. Bern: Peter Lang AG; International Academic Publishers, 2007. P. 173-191.

Mousavi S.A. The Hazaras of Afghanistan: An Historical, Cultural, Economic and Political Study. N.Y.: St. Martin's Press, 1997. https://doi.org/10.4324/9781315026930

Olszewska Z. Quetta's Sectarian Violence and the Global Hazara Awakening // Middle East Report. Vol. 266 (Spring 2013).

Schetter C. Ethnicity and the Political Reconstruction of Afghanistan // ZEF Working Paper Series. 2005. No. 3. Bonn: University of Bonn; Center for Development Research (ZEF).

Schurmann H.F. The Mongols of Afghanistan: An Ethnography of the Mongols and Related Peoples of Afghanistan. 'S-Gravenhage: Mouthon \& Co, 1962.

Verardi G. Buddhism in North-Western India and Eastern Afghanistan, Sixth to Ninth Century AD. Kyoto: Institute for Research in Humanities Kyoto University, 2012.

Wafayezada M. Ethnic Politics and Peacebuilding in Afghanistan: The Root Causes of Political Conflicts and the Problems of Democratic Transition. Saarbrucken: Scholar Press, 2013.

Wilder A.A. House Divided: Analyzing the 2005 Afghan Elections. Kabul: Afghanistan Research and Evaluation Unit, 2005.

Zulfacar M. The Pendulum of Gender Politics in Afghanistan // Central Asian Survey. 2006. Vol. 25. No. 1-2. P. 27-59. https://doi.org/10.1080/02634930600903007

Seitov, Erik $M$.

\section{Replication of the Historical Experience of Self-Organization in a Foreign Cultural Environment: The Case of the "Katib" Hazara Student Association in Moscow}

\section{DOI: $10.33876 / 2311-0546 / 2021-4 / 230-250$}

The article is devoted to the migrants from the Islamic Republic of Afghanistan - the 
Hazara ethnic group - in Moscow. The Katib Student Scientific and Cultural Association in the Russian Federation provides an example of a group's internal self-organization and socialization in a foreign cultural society. The mechanisms of adaptation are based on historical experience and often refer to the region of origin. Relations with other "Afghan" ethnic groups in Moscow largely repeat the situation in Afghanistan itself.

Keywords: Moscow, Hazara ethnic group, migration, Afghanistan, national organizations

For Citation: Seitov, E.M. 2021. Replication of the Historical Experience of SelfOrganization in a Foreign Cultural Environment: The Case of the "Katib" Hazara Student Association in Moscow. Herald of Anthropology (Vestnik Antropologii) 4: 230-250.

Author Info: Seitov, Erik M. - PhD student, Institute of Ethnology and Anthropology RAS (Moscow, Russia). E-mail: telcorp@list.ru

Funding: The research is published as part of the Research Plan of the Institute of Ethnology and Anthropology RAS

\section{References}

Akbar, S.A. 1976. Millennium and Charisma among Pathans: A Critical Essay in Social Anthropology. London: Routledge; Kegan Paul.

Canfield, R. 1972. Hazara Integration into the Afghan State: Some Changing Relations between Hazaras and Afghan Officials. New York: The Afghanistan Council.

Emadi, H. 1995. Exploring Iran's Revolution: The Radicalization of the Shiite Movement in Afghanistan. Middle Eastern Studies 31 (1): 1-12.

Fayz, Muhammad. 1998. Kabul Under Siege: Fayz Muhammad's Account of the 1929 Uprising, translated by R.D. McChesney. Princeton: Markus Wiener Publishers.

Ferdinand, K. 1959. Preliminary Notes on Hazara Culture (The Danish Scientific Mission to Afghanistan (1953-1955). Kobenhavn: Ejnar Munksgaard.

Ferdinand, K. 1962. Nomad Expansion and Commerce in Central Afghanistan. Vol. 4. Kobenhavn: Folk. Giustozzi, A. 2008. Afghanistan, Transition without End: An Analytical Narrative on State-making. In Crisis States Working Papers Series 2. London: Crisis States Research Centre; DESTINE.

Harpviken, B.K. 1996. Political Mobilization among the Hazara of Afghanistan: 1978-1992. Oslo: Departament of Sociology University of Oslo.

Husseini, S.R. 2012. Destruction of Bamiyan Buddhas: Taliban Iconoclasm and Hazara Response. Himalayan and Central Asian Studies 16 (2): 15-50.

Ibrahimi, N. 2017. The Hazaras and the Afghan State: Rebellion, Exclusion and the Struggle for Recognition. London: HURST\&COMPANY.

Laali, A. 1993. Sairey dar Hazarajat [An Overview of Hazarajat]. Qom: Ehsani.

Kirichenko, V.P. 2019. Uchastie hazareitsev Afganistana v siriiskom konflikte [Participation of the Hazaras of Afghanistan in the Syrian Conflict]. Rossiia i musul'manskii mir 4 (314): 70-78.

Kisliakov, V.N. 1973. Hazareitsy, aimaki, mogoly (k voprosu ob ikh proiskhozhdenii i rasselenii) [Hazaras, Aimaqs, Mughals (On the Question of Their Origin and Settlement)]. Sovetskaia etnografiia 4: 130-139.

Korgun, V.G. 2005. Islam i problemy razvitiia Afganistana [Islam and the Problems of Afghanistan's Development]. In Islam $i$ obshchestvennoe razvitie $v$ nachale XXI veka [Islam and Social Development at the Beginning of the 21 Century], edited by V.Y. Belokrenitskii, A.Z. Egorin, and N.Y. Ulchenko, 141-151. Moscow: Kraft.

Minahan, J.B. 2014. Ethic Groups of North, East, and Central Asia. Santa Barbara: ABC-CLIO.

Monsutti, A. 2007. Image of the Self, Image of the Other: Social Organization and the Role of "Ashura" among the Hazaras of Quetta (Pakistan). In The Other Shiites. From the Mediterranean 
to Central Asia, edited by A. Monsutti, S. Naef, and F. Sabahi, 173-191. Bern: Peter Lang AG; International Academic Publishers.

Mousavi, S.A. 1997. The Hazaras of Afghanistan: An Historical, Cultural, Economic and Political Study. New York: St. Martin's Press. https://doi.org/10.4324/9781315026930.

Olszewska, Z. 2013. Quetta's Sectarian Violence and the Global Hazara Awakening. Middle East Report 266 (Spring 2013).

Petrushevskii, I.P. 1960. Zemledelie $i$ agrarnye otnosheniia v Irane XIII-XIV vekov [Agriculture and Agrarian Relations in Iran of the $13-15^{\text {th }}$ Centuries]. Moscow; Leningrad: Izdatel'stvo AN SSSR.

Popkov, V.D. 2003. Soobshchestvo afganskih migrantov v Moskve: voprosy struktury i identichnosti. Zhurnal sotsiologii $i$ sotsial'noi antropologii VI (2): 150-164.

Schetter, C. 2005. Ethnicity and the Political Reconstruction of Afghanistan. ZEF Working Paper Series 3. Bonn: University of Bonn; Center for Development Research (ZEF).

Schurmann, H.F. 1962. The Mongols of Afghanistan: An Ethnography of the Mongols and Related Peoples of Afghanistan. 'S-Gravenhage: Mouthon \& Co.

Sikoev, R.R. 2005. Sufiiskie ordeny v social'no-politicheskoi zhizni Afganistana [Sufi Orders in the Socio-Political Life of Afghanistan]. In Islam i obshchestvennoe razvitie $v$ nachale XXI veka [Islam and Social Development at the beginning of the 21 Century], edited by V.Y. Belokrenitskii, A.Z. Egorin, and N.Y. Ulchenko, 376-385. Moscow: Kraft.

Temirhanov, L. 1972. Hazareitsy (ocherki novoi istorii) [The Hazara Peoples (Essays on Modern History)]. Moscow: Nauka.

Verardi, G. 2012. Buddhism in North-Western India and Eastern Afghanistan, Sixth to Ninth Century $A D$. Kyoto: Institute for Research in Humanities Kyoto University.

Wafayezada, M. 2013. Ethnic Politics and Peacebuilding in Afghanistan: The Root Causes of Political Conflicts and the Problems of Democratic Transition. Saarbrucken: Scholar Press.

Wilder, A.A. 2005. House Divided: Analyzing the 2005 Afghan Elections. Kabul: Afghanistan Research and Evaluation Unit.

Zulfacar, M. 2006. The Pendulum of Gender Politics in Afghanistan. Central Asian Survey 25 (12): 27-59. https://doi.org/10.1080/02634930600903007. 